\title{
Design Of Dipole Microstrip Antenna With Cohen-Minkowski Fractal For 433433 Mhz Frequency
}

\author{
Isman Wahyudi \\ Department Of Electrical Engineering, University Of North Sumatra, Jl. Dr. Mansur No. 9 Padang Bulan, Kec. \\ Medan Baru, Kota Medan 20222
}

\begin{tabular}{|c|c|}
\hline ARTICLE INFO & ABSTRACT \\
\hline Article history: & \multirow{4}{*}{$\begin{array}{l}\text { This final project discusses the design of a dipole microstrip antenna } \\
\text { with Cohen-Minkowski fractals for a frequency of } 433 \mathrm{MHz} \text { which } \\
\text { can be applied to Industrial, Scientific, and Medical (ISM) Band } \\
\text { channels. The microstrip antenna uses a substrate made from FR- } 4 \\
\text { with a thickness of } 1.6 \mathrm{~mm} \text { and a channel impedance of } 75 \\
\text { Antenna design and simulation using AWR Microwave Office } 2004 \\
\text { Software. The results of the design using the Cohen-Minkowski } \\
\text { fractal can minimize the antenna size by } 29 \% \text { iteration-1, and } 40 \% \\
\text { iteration- } 2 \text { so as to give a VSWR value of } 1.02 \text { for the dipole without } \\
\text { iteration, } 1.74 \text { for the iteration- } 1 \text { fractal dipole, and } 1,26 \text { iterations of } \\
\text { fractal dipoles. The return loss resulting from the antenna design is - } \\
37.7 \text { for the dipole without iteration, }-11.29 \text { for the iteration-1 fractal } \\
\text { dipole, and }-18.69 \text { for the iteration- } 2 \text { fractal. Then the gain obtained } \\
\text { from the antenna design is } 4.78 \mathrm{~dB} \text { for the dipole without iteration, } \\
4.91 \mathrm{~dB} \text { for the iteration- } 1 \text { fractal dipole, and } 4.78 \mathrm{~dB} \text { for the iteration- } \\
2 \text { fractal dipole. The radiation pattern generated from the antenna is } \\
\text { unidirectional. }\end{array}$} \\
\hline $\begin{array}{r}\text { Received Aug 05, } 2020 \\
\text { Revised Sep 13, } 2020 \\
\text { Accepted Oct 30, } 2020\end{array}$ & \\
\hline Keywords: & \\
\hline $\begin{array}{r}\text { Antenna } \\
\text { Microstrip } \\
\text { Dipole } \\
\text { Cohen-Minkowski Fractal } \\
\text { Industrial } \\
\text { Scientific } \\
\text { And Medical (ISM) Band }\end{array}$ & \\
\hline
\end{tabular}

This is an open access article under the CC BY-NC license.

\section{Corresponding Author:}

Isman Wahyudi,

Department Of Electrical Engineering,

University Of North Sumatra,

JI. Dr. Mansur No. 9 Padang Bulan, Kec. Medan Baru, Kota Medan 20222.

Email : ismanwahyudi@gmail.com

\section{INTRODUCTION}

Fractal geometry has been known for almost a century, the study of fractal antennas is a relatively new research. The term fractal was coined in 1975 by the French mathematician, Benoît B. Mandelbrot. Since Mandelbrot's work various application areas for fractals have been discovered and studied, a particular area of research is fractal electrodynamics. This study shows that fractals have good electromagnetic radiation patterns and advantages over traditional antennas. Such Advantages face the problems of modern wireless communication. Compared to conventional antennas, fractals have a larger bandwidth and are of the same size. With fractal antennas, it is possible to achieve a resonant frequency that is multiband and this frequency is not harmonic.

The dipole microstrip antenna is a planar element consisting of a pair of thin conductor blades located on the dielectric surface. The dipole microstrip has a shape that resembles a patch microstrip, only there is a slight difference in the ratio of length to width. Compared to patch microstrips, dipole microstrips have several advantages, namely smaller size and wider bandwidth . 
In this study, we will discuss the design of a dipole microstrip antenna with Cohen-Minkowski fractals for a frequency of $433 \mathrm{MHz}$. The $433 \mathrm{MHz}$ frequency is included in the Industrial, scientific and medical (ISM) channel specifications intended for local applications in industry, scientific testing, and medical applications.

\section{RESEARCH METHOD}

The methodology used in writing is as follows:

a. Study of literature

By reading theories related to the topic of the Final Project which consists of reference books either owned by the author or from libraries as well as from articles, journals, internet services, etc.

b. Design and Simulation

It is the process of designing a dual-band dipole microstrip antenna starting from the selection of materials, designing the antenna geometry and simulating it using structural simulator software, high frequency..

c. Analysis Study

That is a series of processes carried out to find out whether the designed antenna has worked as expected.

\section{RESULTS AND DISCUSSIONS}

3.1 Initial Simulation of Microstrip Dipole Antenna Without Iteration Frequency $433 \mathbf{~ M H z}$

After obtaining the dimensional characteristics of the antenna, the next process is to perform a simulation. The results of the initial design simulation of the antenna can be seen in Figure 1.

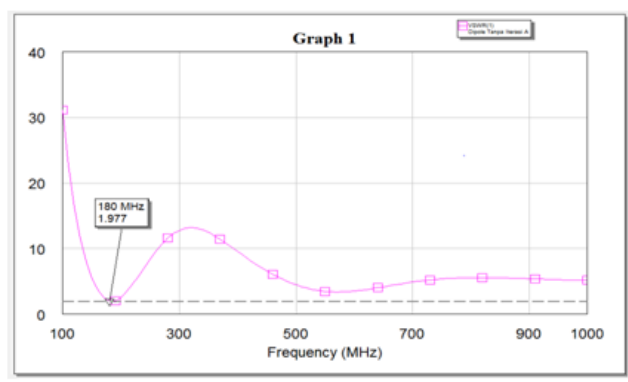

Figure 1. Initial Antenna Simulation

\section{a. Optimization}

From the simulation results of a microstrip dipole antenna without an iteration frequency of $433 \mathrm{MHz}$, it is known that the antenna has not worked well at the desired frequency, so the process of optimizing the dimensions of the antenna needs to be done. Optimization is done by changing the length of the arm or patch of the dipole antenna so that the desired results are obtained. The results of the optimization can be seen in the Appendix.

\section{b. Antenna Simulation Results After Optimization}

After designing and optimizing the characteristics of the microstrip dipole antenna without iteration for a frequency of $433 \mathrm{MHz}$, the VSWR value of 1.06 is obtained as shown in Figure 2. 


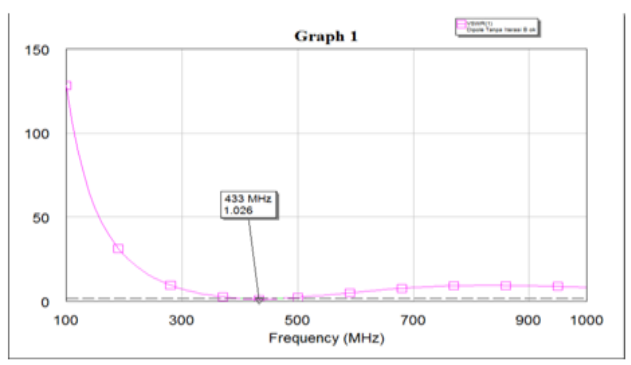

Figure 2. Antenna VSWR Graph Without Iteration Frequency $433 \mathrm{MHz}$

From the simulation results it is also known that the radiation pattern from the antenna is unidirectional where the radiation pattern is more effective in certain directions only, and the Gain obtained from the microstrip dipole antenna without iteration Frequency $433 \mathrm{MHz}$ is $4.78 \mathrm{~dB}$ as shown in Figure 3.

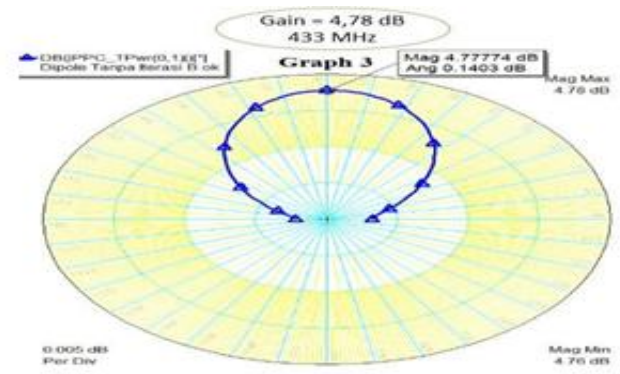

Figure 3. Radiation Pattern and Antenna Gain Without Iteration

Return loss obtained from a microstrip dipole antenna without an iteration frequency of 433 $\mathrm{MHz}$ is $-37.7 \mathrm{~dB}$ as shown in Figure 4.

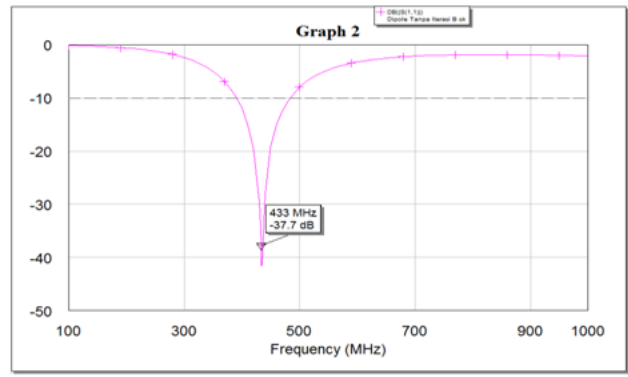

Figure 4. Graph of Antenna Return Loss Without Iteration Frequency $433 \mathrm{MHz}$

\subsection{Preliminary Simulation of Cohen-Minkowski Fractal Dipole Microstrip Antenna $433 \mathrm{MHz}$ Frequency Iteration-1}

After obtaining the size of the Cohen-Minkowski fractal dipole microstrip antenna iteration-1, the next process is to perform simulations. The simulation results from the design of the iteration- 1 Cohen-Minkowski fractal dipole microstrip antenna are shown in Figure 5. 


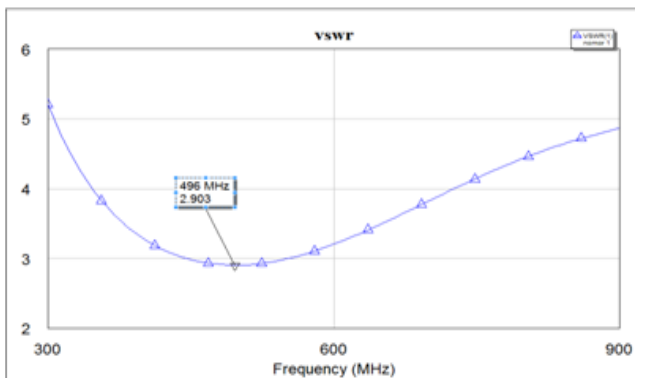

Figure 5. Antenna Simulation Results before Optimization Based on Figure 4.5, VSWR results from a dipole microstrip antenna

Cohen-Minkowski fractal iteration-1 does not work well at the desired frequency. To get a better VSWR value and at the desired frequency, an optimization process is carried out.

\section{a. Optimization}

Optimization in the design of the iteration-1 Cohen-Minkowski fractal dipole microstrip antenna is done by changing the length of each segment on the patch antenna from $1 \mathrm{~mm}$ to $5 \mathrm{~mm}$. After the optimization process is carried out, the VSWR is 1.8 at a frequency of $419 \mathrm{MHz}$. Because the results have not fallen at the desired frequency, it is done optimization on the patch length of the iteration-1 fractal dipole microstrip antenna starting from $1 \mathrm{~mm}$. After getting the desired results on optimization, then the best VSWR value is 1.7 at a frequency of $433 \mathrm{MHz}$. Complete data regarding the optimization process can be seen in the Appendix.

Based on the optimization results, the dimensions of the iteration-1 Cohen-Minkowski fractal dipole microstrip antenna obtained are as shown in Figure 6 with the dimensional characteristics in Table 1.

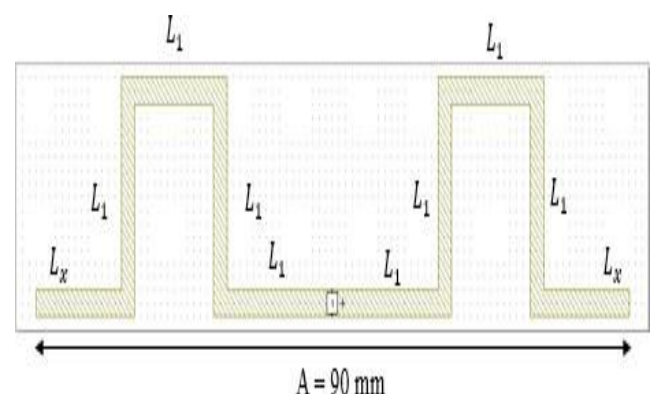

Figure 6. Antenna Dimensions After Optimization

Table 1. Antenna Dimensions Iteration-1 After Optimization

\begin{tabular}{ccc}
\hline Size & Symbol & Score \\
\hline $\begin{array}{c}\text { Patch length } \\
\text { antenna }\end{array}$ & $\mathrm{A}$ & $90 \mathrm{~mm}$ \\
$\begin{array}{c}\text { Length of one segment } \\
\text { fractal antenna }\end{array}$ & & $16 \mathrm{~mm}$ \\
$\quad \begin{array}{c}\text { Edge sleeve length } \\
\text { antenna after optimization } \\
\text { Antenna patch width } \\
\begin{array}{c}\text { Substrate length } \\
\text { antenna }\end{array}\end{array}$ & - & $13 \mathrm{~mm}$ \\
Antenna substrate width & - & $2 \mathrm{~mm}$ \\
& & $96 \mathrm{~mm}$ \\
\end{tabular}




\section{b. Simulation Results of Iteration-1. Antenna}

After designing and optimizing the characteristics of the iteration-1 Cohen-Minkowski fractal dipole microstrip antenna for a frequency of $433 \mathrm{MHz}$, the VSWR value of 1.7 is obtained as shown in Figure 7.

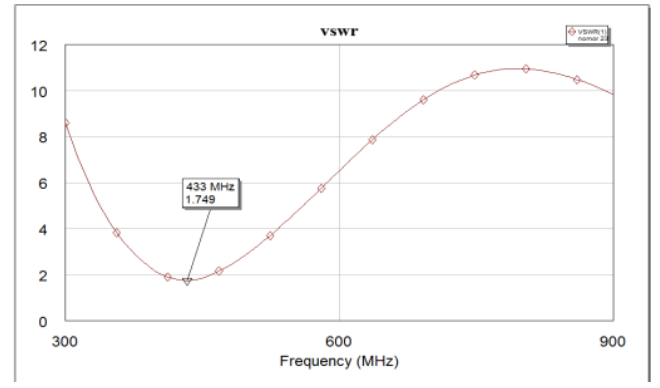

Figure 7. VSWR Graph of Iteration-1 Antenna Frequency $433 \mathrm{MHz}$

From the simulation results, it is also known that the radiation pattern from the antenna is unidirectional where the radiation pattern is more effective in certain directions, and the gain obtained from the antenna is $4.91 \mathrm{~dB}$ as shown in Figure 8.

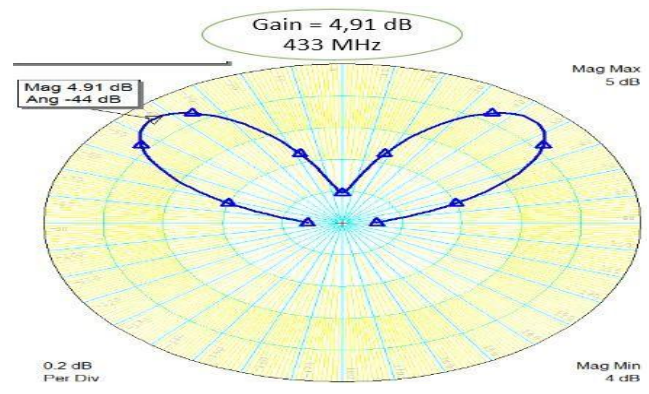

Figure 8. Radiation Pattern and Antenna Gain Iteration-1 Frequency $433 \mathrm{MHz}$

Return loss obtained from the Cohen-Minkowski fractal dipole microstrip antenna iteration-1 frequency of $433 \mathrm{MHz}$ is $-11.29 \mathrm{~dB}$ as shown in Figure 9.

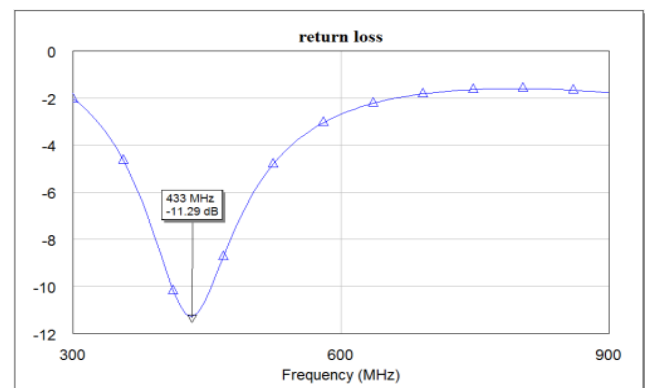

Figure 9. Graph of Return loss Antenna Iteration-1 Frequency $433 \mathrm{MHz}$

\subsection{Initial Simulation of Cohen-Minkowski Fractal Dipole Antenna Iteration-2 Frequency 433} $\mathrm{MHz}$ 
After obtaining the size of the Cohen-Minkowski fractal dipole microstrip antenna iteration-2, the next process is to perform simulations. The simulation results from the design of the CohenMinkowski fractal dipole microstrip antenna iteration-2 are shown in Figure10.

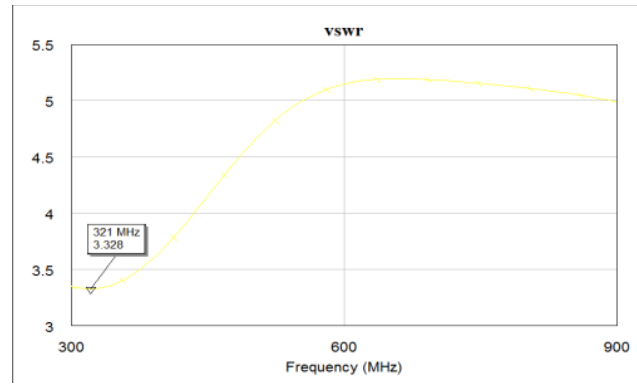

Figure10. Results of Iteration-2 Antenna Simulation before Optimization

Based on Figure 10, VSWR results from fractal dipole microstrip antennas Cohen-Minkowski iteration-2 has not worked well at the desired frequency. To get a better VSWR value and at the desired frequency, an optimization process is carried out.

\section{a. Optimization}

Optimization in the design of the Cohen-Minkowski fractal dipole microstrip antenna iteration-2 is done by changing the length of each segment on the patch antenna from $1 \mathrm{~mm}$ to $5 \mathrm{~mm}$. Before the optimization process is carried out, a VSWR of 1.3 is obtained at a frequency of $335 \mathrm{MHz}$. Due to results it has not fallen at the desired frequency, then optimization is carried out on the iteration2 fractal dipole microstrip patch antenna starting from $1 \mathrm{~mm}$. After getting the desired results on optimization, the VSWR value is 1.2 at a frequency of $433 \mathrm{MHz}$. Complete data regarding the optimization process can be seen in the Appendix.

Based on the optimization results, the dimensions of the iteration-2 Cohen-Minkowski fractal dipole microstrip antenna obtained are as shown in Figure 11 with the antenna dimensions in Table 2 .

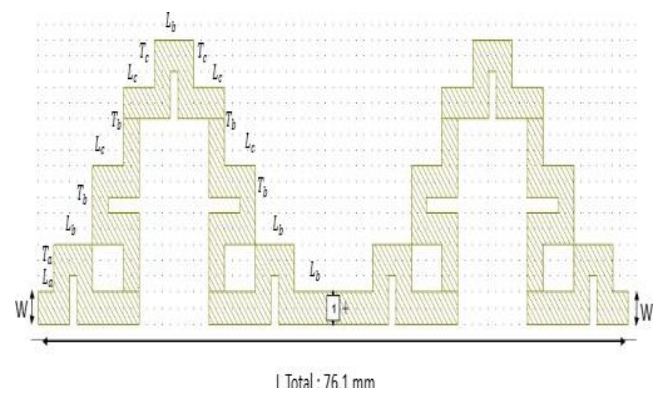

Figure 11. Dimensions of Iteration-2 Antenna After Optimization Process

Table 2. Dimensions of Iteration-2 Antenna After Optimization

\begin{tabular}{ccc}
\hline Size & Symbol & Score \\
\hline $\begin{array}{c}\text { Patch length } \\
\text { antenna }\end{array}$ & L Total & $76 \mathrm{~mm}$ \\
$\begin{array}{c}\text { Length of one segment } \\
\text { antenna }\end{array}$ & $2 \mathrm{~mm}$ \\
$\begin{array}{c}\text { Length of one segment } \\
\text { antenna }\end{array}$ & $5 \mathrm{~mm}$ \\
$\begin{array}{c}\text { Length of one segment } \\
\text { antenna }\end{array}$ & $4 \mathrm{~mm}$ \\
One segment height & $3 \mathrm{~mm}$ \\
\hline
\end{tabular}




\begin{tabular}{|c|c|c|}
\hline $\begin{array}{c}\text { antenna } \\
\text { One segment height }\end{array}$ & & $5 \mathrm{~mm}$ \\
\hline $\begin{array}{c}\text { One segment height } \\
\text { antenna }\end{array}$ & & $3 \mathrm{~mm}$ \\
\hline Antenna patch width & W & $2 \mathrm{~mm}$ \\
\hline $\begin{array}{l}\text { Substrate length } \\
\text { antenna }\end{array}$ & - & $80 \mathrm{~mm}$ \\
\hline Antenna substrate width & - & $21 \mathrm{~m}$ \\
\hline
\end{tabular}

\section{b. Antenna Simulation Results}

After designing and optimizing the size of the iteration-2 Cohen-Minkowski fractal dipole microstrip antenna for a frequency of $433 \mathrm{MHz}$, the VSWR value of 1.2 is obtained, as shown in Figure12.

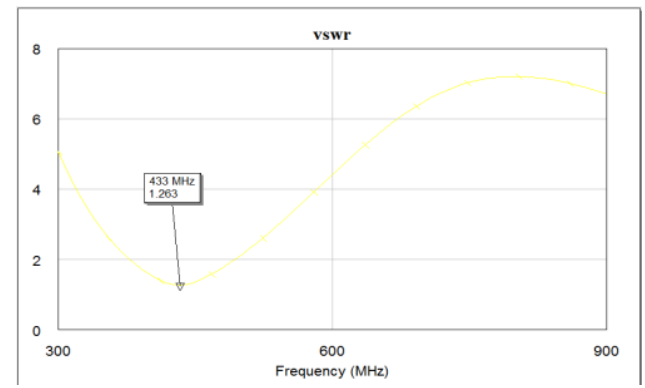

Figure 12. Graph of VSWR Antenna Iteration-2 Frequency $433 \mathrm{MHz}$

From the simulation results, it is also known that the radiation pattern of the antenna is unidirectional where the radiation pattern is more effective in certain directions only. The gain obtained from the Cohen-Minkowski fractal dipole microstrip antenna with a frequency of $433 \mathrm{MHz}$ is $4.78 \mathrm{~dB}$ as shown in Fig 13.

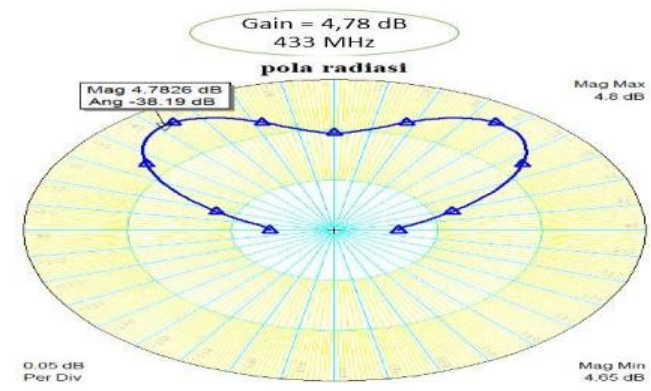

Figure 13. Radiation Pattern and Antenna Gain Iteration-2 Frequency $433 \mathrm{MHz}$

Return loss obtained from the Cohen-Minkowski iteration-2 fractal dipole microstrip antenna with a frequency of $433 \mathrm{MHz}$ is $-18.69 \mathrm{~dB}$ as shown in Figure 14 . 


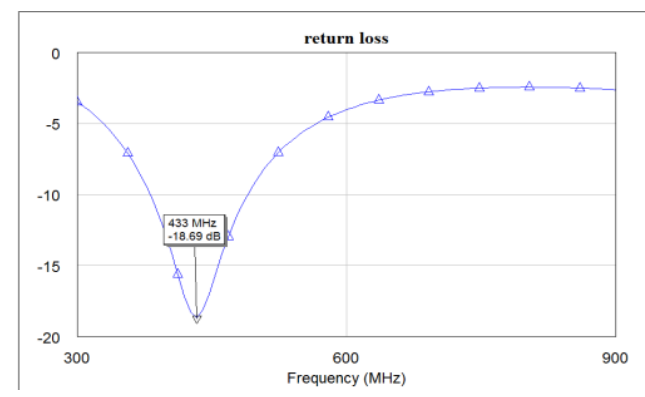

Figure 14. Graph of Return loss Antenna Iteration-2 Frequency $433 \mathrm{MHz}$

\section{CONCLUSION}

The Cohen-Minkowski fractal dipole microstrip antenna has been successfully designed and can work at a frequency of $433 \mathrm{MHz}$.

The VSWR value obtained from the antenna design is 1.02 for the dipole without iteration, 1.74 for iteration-1, and 1.26 for iteration-2, has reached the expected antenna specifications contained in Table 1.

The smaller the fractal size, the better the VSWR value obtained.

Return loss obtained from the design of the antenna, -37.7 for the dipole without iteration, 11.29 for the fractal iteration- 1 , and -18.69 for the fractal iteration-2, and have reached the antenna specifications expected in Table 1.

Gain The results obtained in the antenna design are $4.78 \mathrm{~dB}$ for no iteration, $4.91 \mathrm{~dB}$ for fractal iteration-1, and $4.78 \mathrm{~dB}$ for fractal iteration-2, and have not reached the expected antenna specifications in Table 1.

Things that must be considered when simulating a Cohen-Minkowski fractal microstrip antenna with a frequency of $433 \mathrm{MHz}$ are the dimensions of the patch antenna, the size of the fractal, and the distance between the two patch dipoles.

The radiation pattern obtained in the antenna design is unidirectional, and has reached the expected antenna specifications in Table 1.

Judging from the analysis and discussion of the shape and size of the antenna, the microstrip dipole antenna with iteration-2 Cohen-Minkowski fractal at a frequency of $433 \mathrm{MHz}$ which is applied to the Industrial, Scientific, and Medical (ISM) Band channel can minimize the dimensions of the antenna without fractals by $40 \%$.

\section{REFERENCES}

Lopes, Filipe Monteiro. "Fractal Antennas For Wireless Communication Systems". Universitas De Do Porto. 2009. Hal: 15-22.

Garg, Ramesh. 2001. Microstrip Antenna Design Handbook. 1st ed. Boston, MA: Artech House.

James, J. R, and P. S Hall. 1989. Handbook Of Microstrip Antennas. 1st ed. London, U.K.: P. Peregrinus on behalf of the Institution of Electrical Engineers.

Hill Richard, " The New International Telecommunication Regulations and The Internet", Springer-Verlag GmbH Berlin Heidelberg, 2014

Sinaga, Apli Nardo. 2014. Studi Perancangan Antena Susun Mikrostrip Patch Segiempat Dual-band (2,4 GHz dan 3,3 GHz). Laporan Tugas Akhir Teknik Elektro Universitas Sumatera Utara.

Balanis, Constantine A. 2005. Antenna Theory. 1st ed. Hoboken, NJ: Wiley Interscience.

Yahya Ahmadi Brata." Studi Perancangan Antena Mikrostrip Dipole Dual-Band Frekuensi 2,3 GHz Dan 3,3 GHz Untuk Aplikasi Broadband Wireless Access". SINGUDA ENSIKOM, VOL.11 NO.30/MEI 2015

Iswandi. 2015 " Rancang Bangun Antena Mikrostrip Dipole untuk Frekuensi 2,4 GHz ". Departemen Teknik Elektro Fakultas teknik. Universitas Sumatera Utara.

Dwi Putri Kusumadewi, Nachwan Mufti, Yuyu Wahyu. "Perancangan dan Realisasi Antena Mikrostrip 4 Larik Dipole Pada frekuensi 3,3-3,4 GHz.

Untuk Aplikasi WIMAX". Teknik Telekomunikasi, Fakultas IImu Terapan, Universitas Telkom. Tugas Akhir 2012 
Nitali Garg, Zarren Aijaz. 2012. "Antena Mikrostrip Dipole Dualband untuk Aplikasi Wideband". ISSN International Journal of Computer Technology and Electronics Engineering (IJCTEE), Vol. 2, No. 6, Desember 2012

Jamaluddin, M.H.; Rahim, M.K. A.; Aziz, M. Z. A. Abd.; Asrokin, "Microstrip dipole antenna for WLAN application". IEEE conference publications, Publication Year: 2005, Page(s): 30 - 33.

Yadava, R. L. 2011. Antenna And Wave Propagation. New Delhi: PHI Learning Private Limited.

Kamal A.Rahim, Mohamad.2008. "Design And Development Of Fractal Anntena For Ultra High Frequency Band Application". Fakulti Kejuruteraan Elektrik. Universiti Teknologi Malaysia.

Syarifah Asyura. "Rancang Bangun Antena Yagi-Uda Cohen Minkowski pada Frekuensi 433 MHz ". SINGUDA ENSIKOM. VOL.13 NO.37/DESEMBER 2015

Syed Uvaid Ullah, Dr. R. K. Baghel, Sami Siddiqi. "Efficient Wearable Electro-Textile Antennausing Minkowski Fractal Geometry With Tuning Holes". ISSN, INTERNATIONAL JOURNAL OF TECHNOLOGY ENHANCEMENTS AND EMERGING ENGINEERING RESEARCH (IJTEEE). Vol. 3, no. 6, 2015.

Paridhi Mudgal, Rupesh Tomar, Gaurav Chaitanya." Design and Analysis of Miniaturized Cohen Minkowski Patch Hybridized Fractal Antenna ". ISSN. International Journal of Advanced Research in Computer Engineering \& Technology (IJARCET). Vol.5, No. 5, May 2016.

Suman Lata, Varun Kumar. " Design and Simulation of Minkowski Fractal Patch Antenna on SOI Substrate for Next Generation Wireless Networks “. International Journal of Emerging Technology and Advanced Engineering (IJETAE). Vol. 3, No. 8, August 2013.

Rini Mulia Sari." Studi Antena Yagi-Uda Fraktal Cohen-Minkowski Untuk Frekuensi 433 MHz Iterasi-2 ". SINGUDA ENSIKOM. Departemen Teknik Elektro Fakultas Teknik USU. 2016.

Syaifullah Agus Setyo Nugroho. "Rancang Bangun Sistem Pemantauan Pada Band ISM". Jurusan Teknik Elektro, Fakultas Teknologi Industri, Institut Teknologi Sepuluh November, Surabaya. 